\title{
Localization of NMDA receptors in the cerebral cortex: a schematic overview
}

\author{
Correspondence \\ F. Conti \\ Istituto di Fisiologia Umana \\ Università di Ancona \\ Via Tronto 10/A \\ Torrette di Ancona \\ I-60020 Ancona \\ Italy \\ Fax: 39712206052 \\ E-mail: f.conti@popcsi.unian.it \\ The data reported in this paper \\ are part of a lecture presented \\ at the XI Annual Meeting of the \\ Federação de Sociedades de \\ Biologia Experimental, Caxambu, \\ MG, Brasil, August 21-24, 1996. \\ Research supported by the \\ Ministero dell'Università e della \\ Ricerca Scientifica e Tecnologica, \\ NATO, and Consiglio Nazionale \\ delle Ricerche.
}

Received January 24, 1997 Accepted February 14, 1997

\begin{abstract}
The fundamental role of N-methyl-D-aspartate (NMDA) receptors in many cortical functions has been firmly defined, as has its involvement in a number of neurological and psychiatric diseases. However, until recently very little was known about the anatomical localization of NMDA receptors in the cerebral cortex of mammals. The recent application of molecular biological techniques to the study of NMDA receptors has provided specific tools which have greatly expanded our understanding of the localization of NMDA receptors in the cerebral cortex. In particular, immunocytochemical studies on the distribution of cortical NMDA receptors have shown that NMDA receptors are preferentially localized on dendritic spines, have disclosed an unknown fraction of presynaptic NMDA receptors on both excitatory and inhibitory axon terminals, and demonstrated that cortical astrocytes do express NMDA receptors. These studies suggest that the effects induced by the activation of NMDA receptors are not due solely to the opening of NMDA channels on neuronal postsynaptic membranes, as previously assumed, but that the activation of presynaptic and glial NMDA receptors may mediate part of these effects.
\end{abstract}

Key words

- Glutamate

- Ionotropic receptors

- Autoreceptors

- Heteroreceptors

- Astrocytes

- Neuron-glia signaling

.....................
Glutamate (Glu) receptors of the N-methyl-D-aspartate (NMDA) type have a fundamental role in the functions of the cerebral cortex, being implicated in developmental processes, transmission of sensory information, synaptic plasticity, learning and memory, neurotoxicity, and in a number of neurological and psychiatric diseases $(1,2)$.

NMDA receptors are formed by different subunits belonging to two classes: NMDAR1 (NR1) and NMDAR2 (NR2) (3-7). The first subunit to be characterized, NR1, exhibits the basic features of the NMDA receptor when expressed in Xenopus oocytes (8), and can exist in several isoforms generated by alternative splicing (9). It has recently been shown that targeted disruption of the NR1 gene abolishes classical NMDA neuronal responses (10), thus demonstrating that NR1 is an essential subunit of the NMDA receptor, and confirming previous suggestions based on expression studies of cDNA in heterologous cells and on the widespread distribution of NR1 mRNA in the central nervous system (4). The second class of NMDA receptor subunits, NR2, includes four different subunits, NR2A-D, encoded by separate genes $(3,11-13)$. No splice variants have been reported for NR2A, B, or C, whereas NR2D exists in two forms, NR2D1 
and NR2D2 (13). Electrophysiological experiments indicate that NR2 subunits produce detectable currents only when they are coexpressed with NR1 (3,11-13), and in situ hybridization shows that they are differentially expressed in the brain (3,11-13) and during development $(3,6,14)$. These findings have generated the notion that NR2 subunits play a modulatory role. Indeed, it has been shown that the combination of NR 1 with different NR2 subunits modifies both electrophysiological and pharmacological responses $(3,4,11-13,15-20)$.

Advances in the knowledge of the molecular biology of NMDA receptors have made available, among others, potent and specific tools for studying the localization of these receptors at the cellular level. This minireview succinctly describes the results of a series of recent anatomical investigations on the localization of NMDA receptors in the cerebral cortex of adult mammals. Notwithstanding the limitations inherent in each of the anatomical techniques employed to generate the data reported here (which have been discussed in the original publications), the availability of these probes has made it possible to define with sufficient detail the basic features of the pattern of NMDA receptor localization in the mammalian cerebral cortex.

The outstanding features of NMDA receptor localization and their functional implications can be summarized as described below.

NMDA receptors are present in many but not in all neurons of the cerebral cortex. Moriyoshi et al. (8) reported that "(NMDAR1)....mRNA is expressed in almost all the neuronal cells throughout the brain regions" (p. 36). Since then it has been assumed that virtually all cells express NMDA receptors. Subsequent in situ hybridization and immunocytochemical studies have shown that NMDA receptors exhibit a widespread distribution in the cerebral cortex (21-24), but semiquantitative analyses suggest that the population of cortical neurons not expressing NMDA receptors is likely to be much larger than previously assumed (about 20\%) (22,24).

In situ hybridization and immunocytochemical studies have shown that neurons expressing NMDA receptors appear to be less numerous in layer IV than in layers II-III and V-VI (24). Since the afferent input reaches the cerebral cortex through Gluergic thalamocortical axons mostly in layer IV (25), this observation is in agreement with the notion that thalamocortical transmission is largely mediated by non-NMDA receptors (26-30), and suggests that the impact of NMDA receptor activation on cortical function is more important in late rather than in early stages of cortical processing.

In cortical neurons NMDA receptors are mostly formed by NRI and NR2A and/or $B$ subunits. This statement is supported by the observations that i) NR1, NR2A, and NR2B are highly expressed by cortical neurons, whereas NR2C and D are weakly expressed (3,4,11-13,15,21-24,31-33); ii) NR1 and NR2A and B exhibit similar distribution patterns, both at the light and at the electron microscopic level (3,11-13,15,24,31-33); iii) NR1 and NR2A/B immunoreactivity (IR) is colocalized in most cortical neurons (24), and iv) "triple subunit" heteromeric NMDA receptors (NR1 + NR2A + NR2B) are present in the cerebral cortex (6).

However, given that few studies have been devoted to the analysis of NR2C and D expression in the cerebral cortex, we cannot rule out a contribution of NR2C and D, and since both NR2C and NR2D determine important biophysical properties $(15,20)$, it follows that the functional properties of cortical NMDA receptors cannot be inferred on the basis of present knowledge.

The large majority of NMDA receptors are located postsynaptically on dendrites and dendritic spines. Electron microscopic immunocytochemical studies have shown that both NR1 and NR2A/B IRs are mostly 
present on dendrites and dendritic spines $(21,23,24,31,32)$. This observation is consistent with i) the location of axon terminals forming asymmetric synapses (34) and the nature and location of Glu+ axon terminals $(35,36)$; ii) previous indications from radioligand binding (37-41) and in situ hybridization (8; for a discussion, see 22) studies, and iii) the results of electrophysiological (42) and combined electrophysiological$\mathrm{Ca}^{2+}$ imaging investigations (43). Overall, this evidence indicates that the bulk of the effects of NMDA receptor activation is generated at distal dendrites and spines, and supports the view expressed by several investigators that dendritic spines in cortical neurons are the site of biophysical events underlying complex integrative properties of cortical neurons (44-48).

NMDA receptors are preferentially expressed by pyramidal neurons. Analysis of the morphology of NR1 and NR2A/B+ neurons showed that in rat neocortex the large majority (about $70 \%$ ) of all labeled neurons are pyramidal, and that this proportion is higher in layers II, III, V and VI $(21,23,24)$. This conclusion is supported by the following observations: i) as reported in the preceding paragraph, NMDA receptors are preferentially located on dendritic spines, which is a typical, though not exclusive, attribute of pyramidal neurons (49-51), and ii) Thomson and collaborators (52) studied excitatory synaptic connections between pairs of cortical neurons recorded in cortical slices from adult rats, and characterized the receptor(s) mediating excitatory postsynaptic potentials (EPSPs). They showed that connections between pyramidal neurons exhibit properties typical of NMDA-mediated processes, even though they are not exclusively mediated by NMDA receptors (53-56). Even though much caution is required when comparing results obtained with different techniques, these results are consistent with the present conclusion in indicating that in all likelihood NMDA receptors display a preferential relation to pyramidal neurons.

Some NMDA receptors are presynaptic auto- and heteroreceptors. Immunocytochemical studies have shown that some axon terminals contain NR1 or NR2A/B IR. Some NR1-NR2A/B+ axon terminals form asymmetric synapses (57; see also 21,23 , 32 ), and given that these axon terminals are either Glu- or aspartate (Asp)-positive $(35,36)$, it follows that NMDA receptors in axon terminals forming asymmetric synapses are autoreceptors that can facilitate Glu (or Asp) release. An unexpected result of our studies has been the identification of NR1 and NR2A/B in some axon terminals forming symmetric synapses (57). Combining preand post-embedding immunocytochemistry, we have shown that all NR1 and NR2A/B+ axon terminals forming symmetric synapses are selectively enriched in gold particles coding for GABA, thus providing the first evidence that some NMDA receptors are heteroreceptors (57). These data suggest that NMDA receptors play a role in the regulation of GABAergic transmission. Overall, these data are consistent with previous demonstrations that presynaptic NMDA receptors contribute to NMDA-mediated phenomena in other regions of the nervous system (58-64).

NMDA receptors are expressed by astrocytes. Whereas the notion that cortical astrocytes express Glu receptors of the $\alpha$-amino3-hydroxy-5-methyl-4-isoxazolepropionate (AMPA) and kainate (KA) types has been firmly established (for reviews, see 65-68), there has been considerable debate on whether astrocytes express NMDA receptors (see 64,69). Compelling evidence for astrocytic expression of NMDA receptor subunits, however, has been provided only recently in immunocytochemical studies using specific antipeptide antibodies (69). The demonstration by electron microscopic immunocytochemistry that some cortical astrocytes do indeed express NR1 $(21,22,69)$ and NR2A/B (69) subunits of the NMDA recep- 
tor indicates that at least part of the effects of NMDA receptor activation in the cerebral cortex may well be due to astrocytic receptors. These receptors can monitor Glu release by neighboring axon terminals $(35,36)$ of thalamic (25) and corticocortical (70) origin, as well as from axon collaterals of cortical Gluergic neurons (71), and therefore they can mediate part of the neuron-glia signaling mechanisms that regulate gene expression and responses to pathological elevations of Glu levels of astrocytes, and may participate in the mechanism(s) subserving activity-dependent cortical plasticity (72).

The data reviewed here indicate that in three years much has been learnt about the cellular and subcellular localization of NMDA receptors in the cerebral cortex. From the present analysis, it appears that in some cases anatomical studies have been confirmatory of previous findings, whereas in other cases immunocytochemical studies have disclosed features such as astrocytic and presynaptic localization that had not been described earlier. Electrophysiological and/or pharmacological analyses are needed to understand their functional role in health and disease.

\section{Acknowledgments}

I thank all the colleagues who participated in the studies cited in the references for their contribution and those who provided information, antibodies, and cDNAs.

\section{References}

1. Collingridge GL \& Watkins JC (1994). The NMDA Receptor. Oxford University Press, Oxford.

2. Conti F \& Hicks TP (1996). Excitatory Amino Acids and the Cerebral Cortex. MIT Press, Cambridge, MA

3. Monyer $\mathrm{H}$, Sprengel R, Schoepfer R, Herb A, Higuchi M, Lomeli $\mathrm{H}$, Burnashev $\mathrm{N}$, Sakmann B \& Seeburg PH (1992). Heteromeric NMDA receptors: molecular and functional distinction of subtypes. Science, 256: 1217-1221.

4. Nakanishi S (1992). Molecular diversity of glutamate receptors and implications for brain function. Science, 258: 597-603.

5. Cik M, Chazot PL \& Stephenson FA (1993). Optimal expression of cloned NMDAR1/NMDAR2 heteromeric glutamate receptors: a biochemical characterization. Biochemical Journal, 296: 877883.

6. Sheng M, Cummings J, Roldan LA, Jan YN \& Jan LY (1994). Changing subunit composition of heteromeric NMDA receptors during development of rat cortex. $\mathrm{Na}$ ture, 368: 144-147.

7. Mori H \& Mishina M (1995). Structure and function of the NMDA receptor channel. Neuropharmacology, 34: 1219-1237.

8. Moriyoshi K, Masu M, Ishii T, Shigemoto R, Mizuno N \& Nakanishi S (1991). Molecular cloning and characterization of the rat NMDA receptor. Nature, 354: 31-37.
9. Zukin RS \& Bennett MVL (1995). Alternatively spliced isoforms of the NMDAR1 receptor subunit. Trends in Neurosciences, 18: 306-313.

10. Forrest $D$, Yuzaki $M$, Soares $H D, N g L$, Luk DC, Sheng M, Stewart CL, Morgan JI, Connor JA \& Curran T (1994). Targeted disruption of NMDA receptor 1 gene abolishes NMDA response and results in neonatal death. Neuron, 13: 325-338.

11. Kutsuwada T, Kashiwabuchi N, Mori M, Sakimura K, Kushiya E, Araki K, Meguro $\mathrm{H}$, Masaki H, Kumanishi T, Arakawa M \& Mishina M (1992). Molecular diversity of the NMDA receptor channel. Nature, 358 36-41.

12. Meguro $H$, Mori $H$, Araki $K$, Kushiya $E$, Kutsuwada T, Yamazaki M, Kumanishi T, Arakawa M, Sakimura K \& Mishina M (1992). Functional characterization of a heteromeric NMDA receptor channel expressed from cloned cDNAs. Nature, 357: 70-74.

13. Ishii $T$, Moriyoshi $K$, Sugihara $H$, Sakurada K, Kadotani H, Yokoi M, Akawaza C, Shigemoto R, Mizuno N, Masu M \& Nakanishi S (1993). Molecular characterization of the family of the N-methyl-Daspartate receptor subunits. Journal of Biological Chemistry, 268: 2836-2843.

14. Farrant M, Feldmeyer D, Takahashi T \& Cull-Candy SG (1994). NMDA-receptor channel diversity in developing cerebellum. Nature, 368: 335-339.
15. Monyer H, Burnashev N, Laurie DJ, Sakmann B \& Seeburg PH (1994). Developmental and regional expression in the rat brain and functional properties of four NMDA receptors. Neuron, 12: 529-540.

16. Williams K, Russell SL, Shen M \& Molinoff PB (1993). Developmental switch in the expression of NMDA receptors occurs in vivo and in vitro. Neuron, 10: 267-278.

17. Williams K, Zappia AM, Pritchett DB, Shen YM \& Molinoff PB (1994). Sensitivity of the $\mathrm{N}$-methyl-D-aspartate receptor to polyamine is controlled by NR2 subunits. Molecular Pharmacology, 45: 803-809.

18. Hollmann M \& Heinemann S (1994). Cloned glutamate receptors. Annual Review of Neuroscience, 17: 31-108

19. McBain CJ \& Mayer ML (1994). N-methylD-aspartic receptor structure and function. Physiological Reviews, 74: 723-760.

20. Molinoff PB, Williams K, Pritchett DB \& Zhong J (1994). Molecular pharmacology of NMDA receptors: modulatory role of NR2 subunits. In: Bloom F (Editor), Neuroscience: From the Molecular to the Cognitive. Progress in Brain Research. Vol. 100. Elsevier, Amsterdam

21. Aoki C, Venkatesan C, Go C-G, Mong JA \& Dawson TM (1994). Cellular and subcellular localization of NMDA-R1 subunit immunoreactivity in the visual cortex of adult and neonatal rats. Journal of Neuroscience, 14: 5202-5222. 
22. Conti F, Minelli A, Molnar M \& Brecha NC (1994). Cellular localization and laminar distribution of NMDAR1 mRNA in the rat cerebral cortex. Journal of Comparative Neurology, 343: 554-565.

23. Huntley GW, Vickers JC, Janssen W, Brose N, Heinemann SF \& Morrison JH (1994). Distribution and synaptic localization of immunocytochemically identified NMDA receptor subunit proteins in sensory-motor and visual cortices of monkey and human. Journal of Neuroscience, 14: 3603-3619.

24. Conti F \& Minelli A (1996). The anatomy of glutamatergic transmission. In: Conti $\mathrm{F}$ \& Hicks TP (Editors), Excitatory Amino Acids and the Cerebral Cortex. MIT Press, Cambridge, MA.

25. Kharazia VN \& Weinberg RJ (1994). Glutamate in thalamic fibers terminating in layer IV of primary sensory cortex. Journal of Neuroscience, 14: 6021-6032.

26. Tsumoto $T$, Masui $H$ \& Sato $H$ (1986). Excitatory amino acid transmitters in neuronal circuits of the cat visual cortex. Journal of Neurophysiology, 55: 469-483.

27. Hagihara K, Tsumoto $T$, Sato $H$ \& Hata $Y$ (1988). Actions of excitatory amino acid antagonists on geniculo-cortical transmission in the cat's visual cortex. Experimental Brain Research, 69: 407-416.

28. Shirokawa $T$, Nishigori A \& Kimura $F$ (1989). Actions of excitatory amino acid antagonists on synaptic potentials of layers II/III neurons of the cat's visual cortex. Experimental Brain Research, 78: 489500.

29. Armstrong-James $M$, Welker E \& Callahan CA (1993). The contribution of NMDA and non-NMDA receptors to fast and slow transmission of sensory information in the rat SI barrel cortex. Journal of Neuroscience, 13: 2149-2160.

30. Weinberg RJ \& Kharazia VN (1996). Excitatory amino acids in thalamocortical transmission. In: Conti F \& Hicks TP (Editors), Excitatory Amino Acids and the Cerebral Cortex. MIT Press, Cambridge, MA.

31. Petralia RS, Yokotani N \& Wenthold RJ (1994). Light and electron microscope distribution of the NMDA receptor subunit NMDAR1 in the rat nervous system using a selective anti-peptide antibody. Journal of Neuroscience, 14: 667-696.

32. Petralia RS, Wang Y-X \& Wenthold RJ (1994). The NMDA receptor subunits NR2A and NR2B show histological and ultrastructural localization patterns similar to those of NR1. Journal of Neuroscience, 14: 6102-6120.
33. Wenzel A, Scheurer L, Kunzi R, Fritschy JM, Mohler H \& Benke D (1995). Distribution of NMDA receptor subunit proteins NR2A, 2B, 2C, and 2D in rat brain. NeuroReport, 7: 45-48.

34. Peters A (1987). Synaptic specificity in the cerebral cortex. In: Gall E \& Cowan M (Editors), Synaptic Function. John Wiley, New York.

35. DeFelipe J, Conti F, Van Eyck SL \& Manzoni T (1988). Demonstration of glutamate-positive axon terminals forming asymmetric synapses in the cat neocortex. Brain Research, 455: 162-165.

36. Conti F, DeFelipe J, Farinas I \& Manzoni T (1989). Glutamate-positive neurons and axon terminals in cat sensory cortex: A correlative light and electron microscopic study. Journal of Comparative Neurology, 290: 141-153.

37. Monaghan DT, Holets VR, Toy DW \& Cotman CW (1983). Anatomical distribution of four pharmacologically distinct $[3 \mathrm{H}]-$ L-glutamate binding sites. Nature, 306: 176-179.

38. Monaghan DT, Bridges RJ \& Cotman CW (1989). The excitatory amino acid receptors: their classes, pharmacology, and distinct properties in the function of the central nervous system. Annual Review of Pharmacology and Toxicology, 29: 365402.

39. Greenamyre JT, Olson JMM, Penney JB \& Young $A B$ (1985). Autoradiographic characterization of N-methyl-D-aspartate-, quisqualate- and kainate-sensitive glutamate binding sites. Journal of Pharmacology and Experimental Therapeutics, 233: 254-263.

40. Monaghan DT \& Cotman CW (1985). Distribution of $\mathrm{N}$-methyl-D-aspartate-sensitive $\mathrm{L}-[3 \mathrm{H}]$ glutamate-binding sites in rat brain. Journal of Neuroscience, 5: 29092919.

41. Maragos WF, Penney JB \& Young AB (1988). Anatomical correlation of NMDA and $\left.{ }^{3} \mathrm{H}\right] \mathrm{TCP}$-labelled receptors in rat brain. Journal of Neuroscience, 8: 493501.

42. Jones KA \& Baughman RW (1988). NMDA- and non-NMDA-receptor components of excitatory synaptic potentials recorded from cells in layer $V$ of rat visual cortex. Journal of Neuroscience, 8: 35223534.

43. Bliss TVP \& Collingridge GL (1993). A synaptic model of memory: long-term potentiation in the hippocampus. Nature, 361: 31-39.
44. Crick F (1982). Do dendritic spines twich? Trends in Neurosciences, 5: 44-46.

45. Jaslove SW (1992). The integrative properties of spiny distal dendrites. Neuroscience, 47: 495-519.

46. Sheperd GM, Woolf TB \& Carnevale NT (1989). Comparisons between active properties of distal dendritic branches and spines: implications for neuronal computations. Journal of Cognitive Neuroscience, 1: 273-286.

47. Gold JI \& Bear MF (1994). A model of dendritic spine $\mathrm{Ca}^{2+}$ concentration exploring possible bases for a sliding synaptic modification threshold. Proceedings of the National Academy of Sciences, USA, 91: 3941-3945

48. Yuste R \& Denk W (1995). Dendritic spines as basic functional units of neuronal integration. Nature, 375: 682-684.

49. Cajal S \& Ramon y (1911). Histologie $d u$ Système Nerveux de l'Homme et des Vertébrés. Maloine, Paris.

50. Feldman ML (1984). Morphology of the neocortical pyramidal cell. In: Peters A \& Jones EG (Editors), Cerebral Cortex. Vol. 1. Cellular Components of the Cerebral Cortex. Plenum Press, New York.

51. DeFelipe J \& Farinas I (1992). The pyramidal neurons of the cerebral cortex: Morphological and chemical characteristics of the synaptic inputs. Progress in Neurobiology, 39: 563-607.

52. Thomson AM \& Deuchars J (1994). Temporal and spatial properties of local circuits in neocortex. Trends in Neurosciences, 17: 119-126.

53. Thomson AM \& West DC (1993). Fluctuations in pyramid-pyramid excitatory postsynaptic potentials modified by presynaptic firing pattern and postsynaptic membrane potential using paired intracellular recordings in rat neocortex. Neuroscience, 54: 329-346.

54. Thomson AM, Deuchars J \& West DC (1993). Single axon EPSPs in neocortical interneurones exhibit pronounced paired pulse facilitation. Neuroscience, 54: 347360.

55. Deuchars J, West DC \& Thomson AM (1994). Relationships between morphology and physiology of pyramid-pyramid single axon connections in rat neocortex in vivo. Journal of Physiology, 478: 423435.

56. Thomson AM, West DC \& Deuchars J (1996). Physiology of glutamatergic transmission in the cerebral cortex. In: Conti $\mathrm{F}$ \& Hicks TP (Editors), Excitatory Amino Acids and the Cerebral Cortex. MIT Press, Cambridge, MA. 
57. DeBiasi S, Minelli A, Melone M \& Conti F (1996). Presynaptic NMDA receptors in the neocortex are both auto- and heteroreceptors. NeuroReport, 7: 2773-2776.

58. Chernevskaya NI, Obokhov AG \& Kristhal OA (1991). NMDA receptor agonists selectively block $\mathrm{N}$-type calcium channels in hippocampal neurons. Nature, 349: 418420.

59. Bustos G, Abarca J, Forray MI, Gysling K, Bradberry CW \& Roth RH (1992). Regulation of excitatory amino acid release by $\mathrm{N}$ methyl-D-aspartate receptors in rat striatum: in vivo microdialysis studies. Brain Research, 585: 105-115.

60. Sherman AD, Hegwood TS, Baruah S \& Waziri R (1992). Presynaptic modulation of amino acid release from synaptosomes. Neurochemical Research, 17: 125-128.

61. Liu $H$, Wang $H$, Sheng $M$, Jan LY, Jan YN \& Basbaum Al (1994). Evidence for presynaptic N-methyl-D-aspartate autoreceptors in the spinal cord dorsal horn. Proceedings of the National Academy of Sciences, USA, 91: 8383-8387.

62. Parnas $H$, Parnas I, Ravin R \& Yudelevitch B (1994). Glutamate and N-methyl-D-aspartate affect release from crayfish axon terminals in a voltage-dependent manner. Proceedings of the National Academy of Sciences, USA, 91: 11586-11590.
63. Siegel SJ, Brose N, Janssen WG, Gasic GP, Jahn R, Heinemann SF \& Morrison JH (1994). Regional, cellular, and ultrastructural distribution of the glutamate receptor subunit NMDAR1 in monkey hippocampus. Proceedings of the National Academy of Sciences, USA, 91: 564-568.

64. Van Bockstaele EJ \& Colago EEO (1996). Selective distribution of the NMDA-R1 glutamate receptor in astrocytes and presynaptic axon terminals in the nucleus locus coeruleus of the rat brain: An immunoelectron microscopic study. Journal of Comparative Neurology, 369: 483496.

65. Pearce B (1993). Amino acid receptors. In: Murphy S (Editor), Astrocytes: Pharmacology and Function. Academic Press, San Diego, CA.

66. Gallo V \& Russell JT (1995). Excitatory amino acid receptors in glia: different subtypes for distinct functions? Journal of Neuroscience Research, 42: 1-8.

67. Blankenfeld v G, Enkuist K \& Kettenmann $H$ (1995). Gamma-aminobutyric acid and glutamate receptors. In: Kettenmann $\mathrm{H}$ \& Ransom B (Editors), Neuroglia. Oxford University Press, New York.
68. Kirchhoff F \& Kettenmann H (1996). lonotropic glutamate receptors in vertebrate glial cells. In: Conti F \& Hicks TP (Editors), Excitatory Amino Acids and the Cerebral Cortex. MIT Press, Cambridge, MA.

69. Conti F, DeBiasi S, Minelli A \& Melone M (1996). Expression of NR1 and NR2A/B subunits of the NMDA receptor in cortical astrocytes. Glia, 17: 254-258.

70. Conti F, Fabri M \& Manzoni T (1988). Glutamate-positive cortico-cortical neurons in the somatic sensory areas I and II of cats. Journal of Neuroscience, 8: 2948-2960.

71. Conti F, Rustioni A, Petrusz P \& Towle AC (1987). Glutamate-positive neurons in the somatic sensory cortex of rats and monkeys. Journal of Neuroscience, 7: 18871901.

72. Conti F, Minelli A \& Pons TP (1996). Changes in glutamate immunoreactivity in the somatic sensory cortex of adult monkeys induced by nerve cuts. Journal of Comparative Neurology, 368: 503-515. 